\title{
Kinetically Controlled Formation of Semi-Crystalline Conjugated Polymer Nanostructures
}

Peter Kei,${ }^{\dagger}$ Mitchell T. Howell,${ }^{\ddagger}$ Carlos A. Chavez, ${ }^{\dagger}$ Joseph C. Mai, ${ }^{\dagger}$ Changwoo Do,${ }^{\S}$ Kunlun

$$
\text { Hong," and Evgueni E. Nesterov }{ }^{*},+, t
$$

'Department of Chemistry, Louisiana State University, Baton Rouge, Louisiana 70803, United States

Department of Chemistry and Biochemistry, Northern Illinois University, DeKalb, Illinois 60115, United States

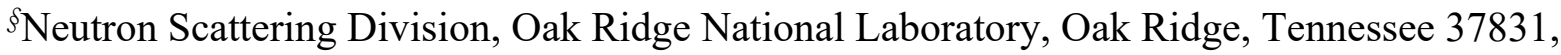
Unites States

${ }^{\#}$ Center for Nanophase Materials Sciences, Oak Ridge National Laboratory, Oak Ridge, Tennessee 37831, Unites States

\section{Supporting Information}




\section{Additional Figures}
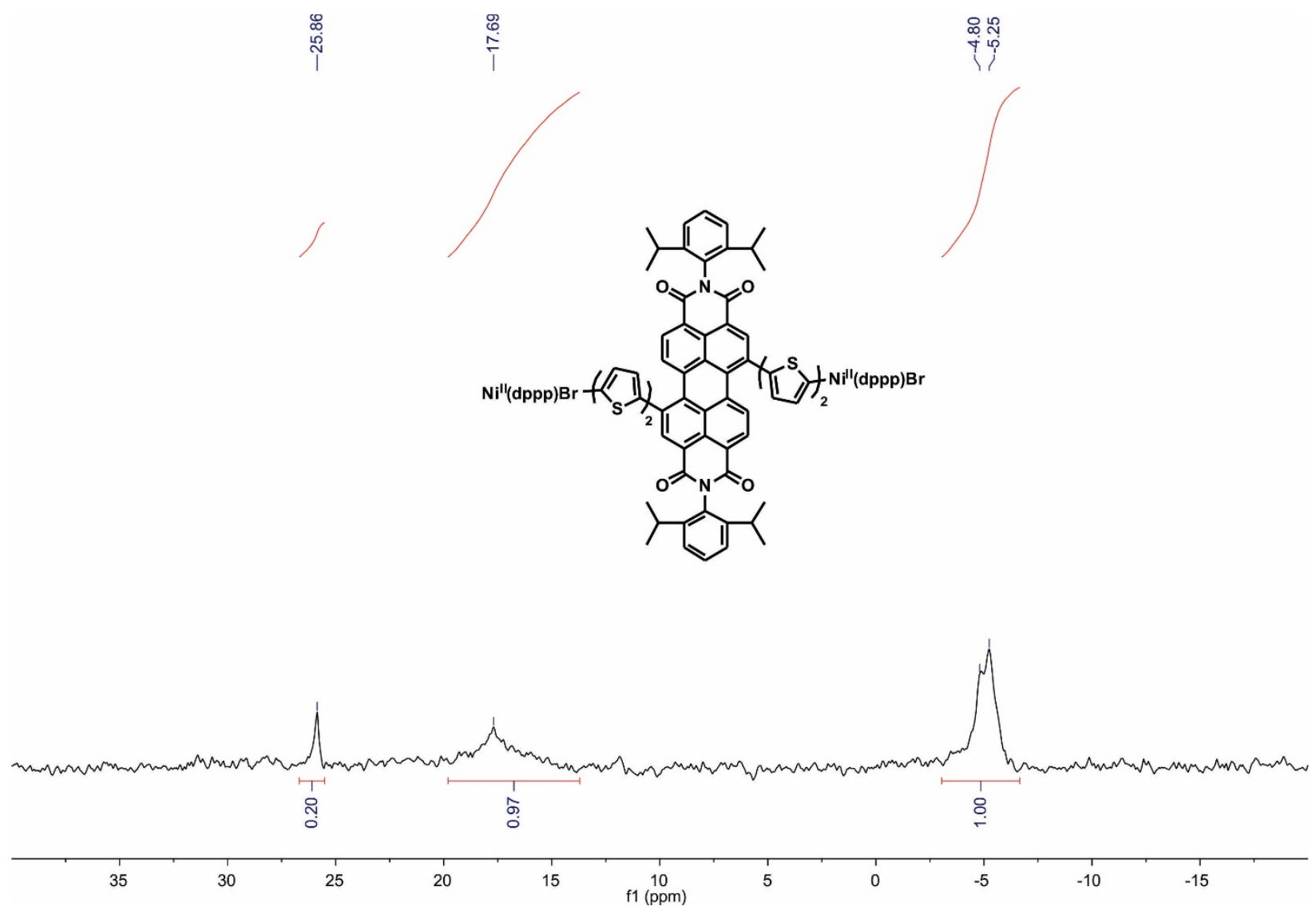

Figure S1. ${ }^{31} \mathrm{P}$ NMR spectrum $(162 \mathrm{MHz})$ of the reaction between dibromide 3 and $\mathrm{Ni}(\mathrm{dppp})_{2}$ in THF at room temperature after $3 \mathrm{~h}$. Broad signals at approx. -4 and $18 \mathrm{ppm}$ correspond to the target product 4, and a smaller signal at $25.9 \mathrm{ppm}$ reflects presence of unreacted $\mathrm{Ni}(\mathrm{dppp})_{2}$.

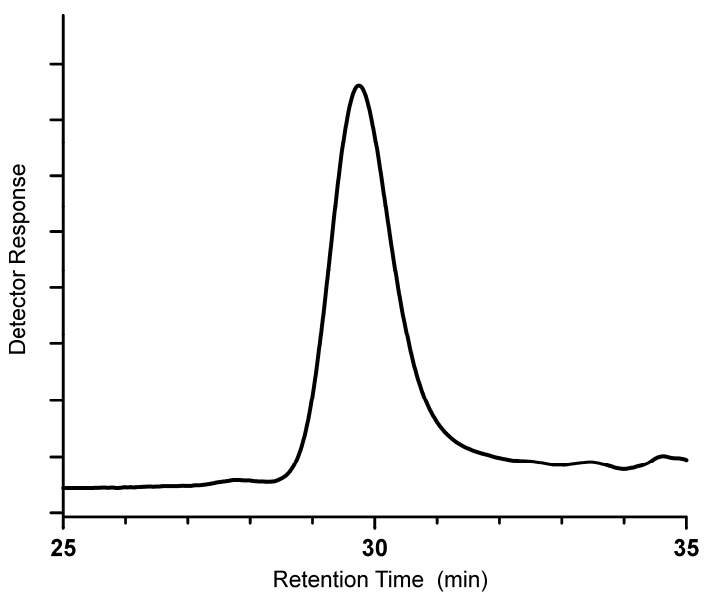

Figure S2. GPC elution trace for polymer P1. 


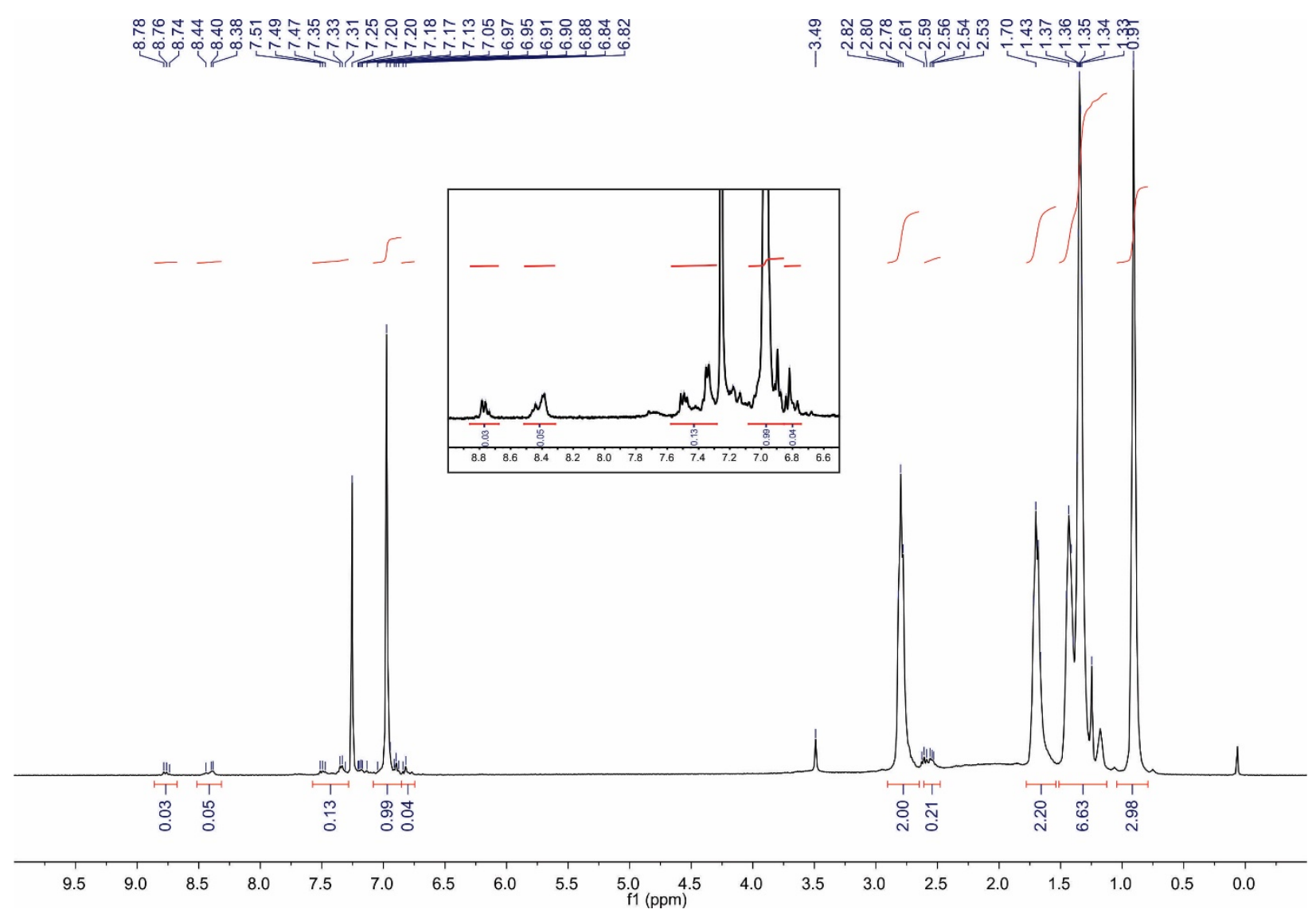

Figure S3. ${ }^{1} \mathrm{H}$ NMR spectrum $\left(400 \mathrm{MHz}, \mathrm{CDCl}_{3}\right)$ of polymer $\mathbf{P 1}$. 

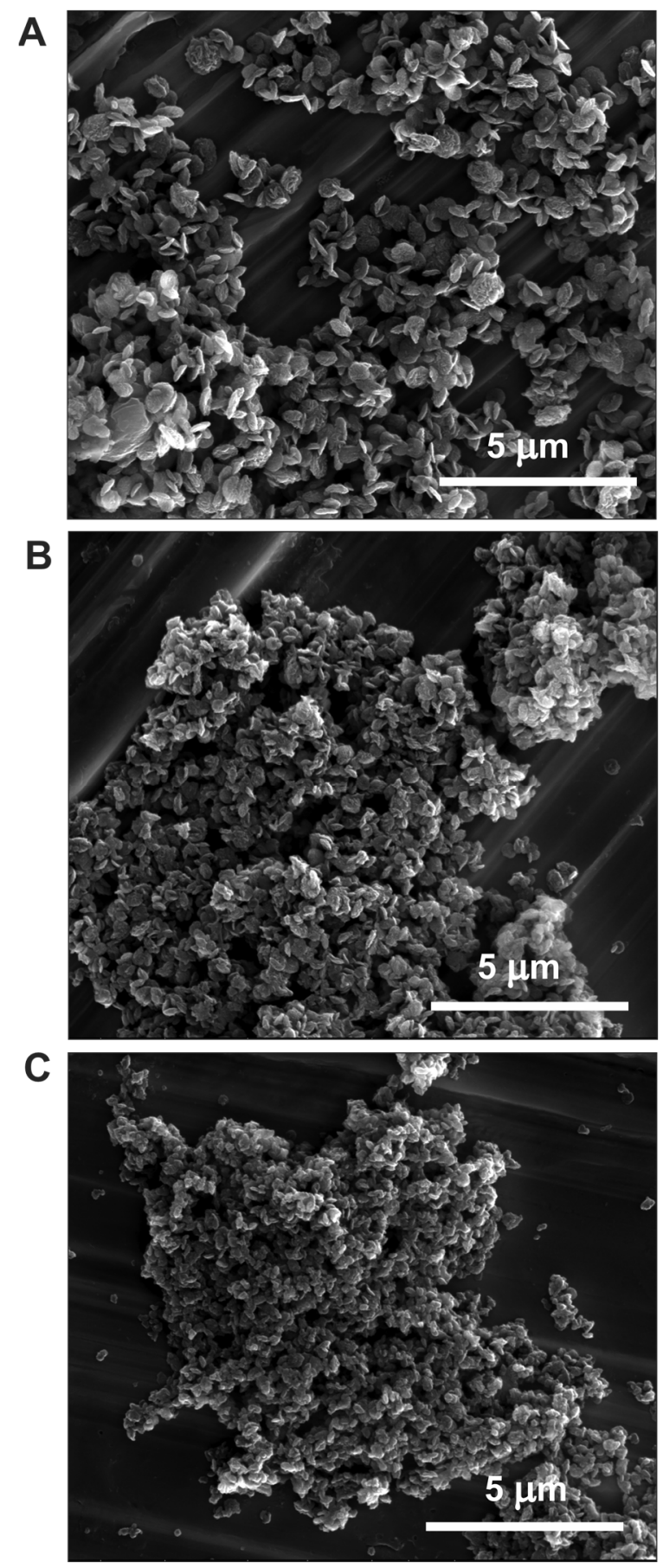

Figure S4. Larger area scanning electron microscopy images of the clusters of PDCI-PT nanoparticles: PDCI-PT $\left(0^{\circ} \mathrm{C}\right)(\mathrm{A}), \operatorname{PDCI}-\mathrm{PT}\left(7^{\circ} \mathrm{C}\right)(\mathrm{B})$, and $\mathrm{PDCI}-\mathrm{PT}\left(22^{\circ} \mathrm{C}\right)(\mathrm{C})$. 


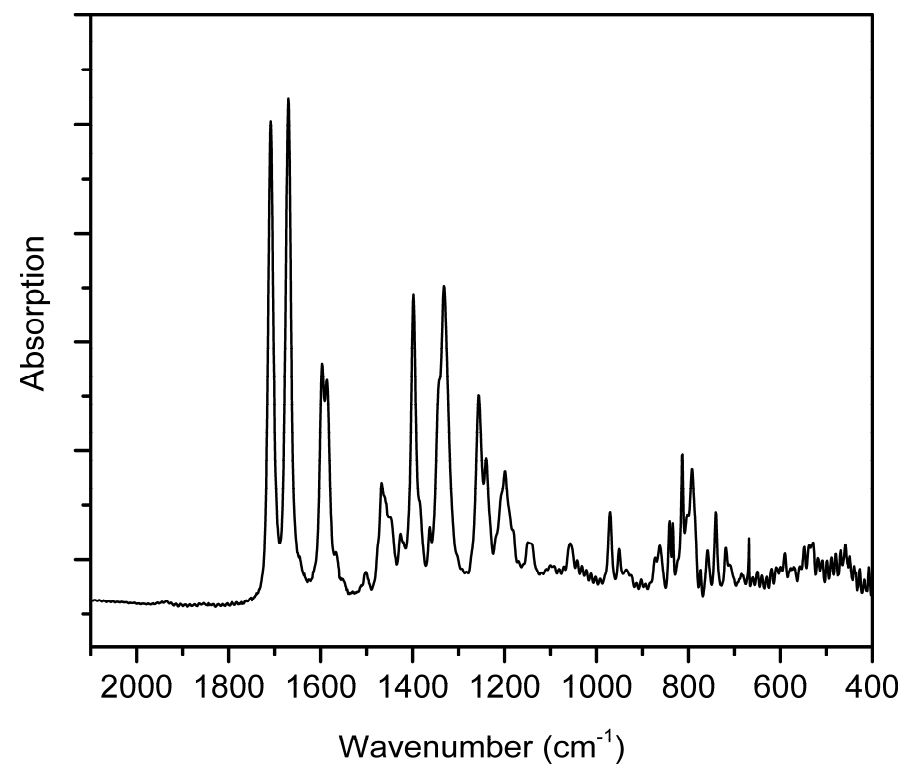

Figure S5. FT-IR spectrum of compound $1(0.19$ wt. \%) in $\mathrm{KBr}$ glass.

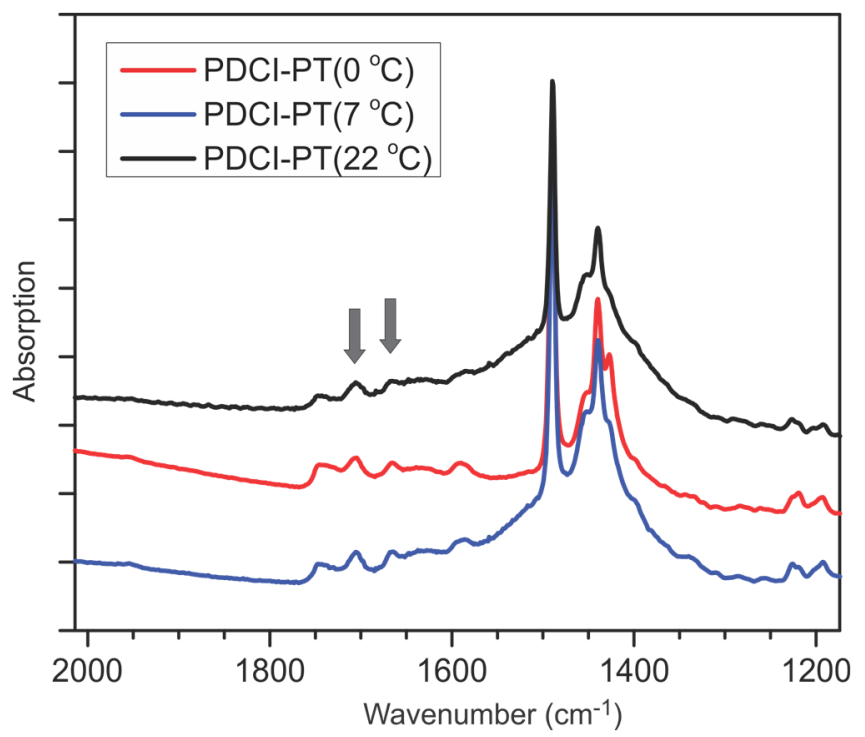

Figure S6. Representative FT-IR spectra of PDCI-PT particles prepared at three different temperatures. Spectra were acquired in $\mathrm{KBr}$ pellets; the $\mathrm{C}=\mathrm{O}$ stretching bands of $\mathrm{PDCI}$ unit (1671 and $1709 \mathrm{~cm}^{-1}$ ) used for quantitative estimates are marked with arrows. 

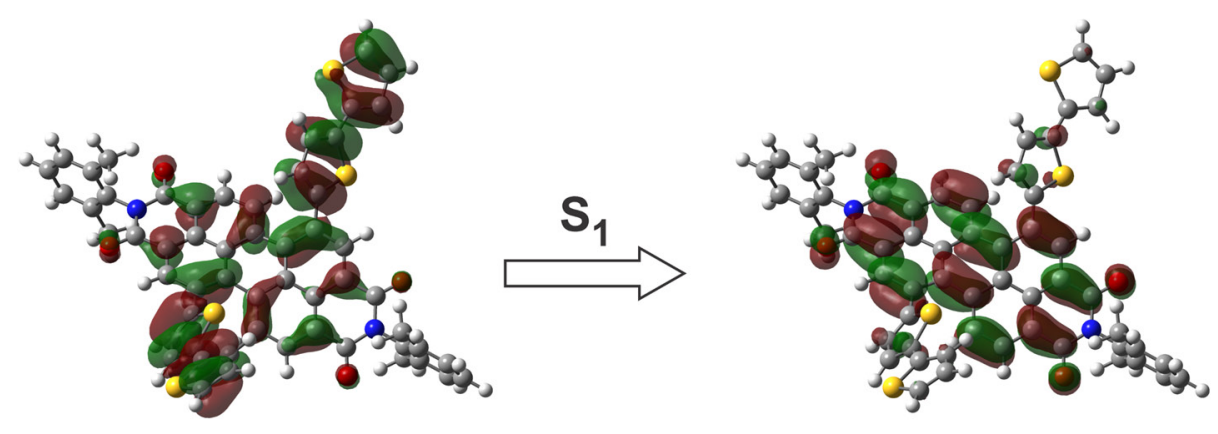

HOMO

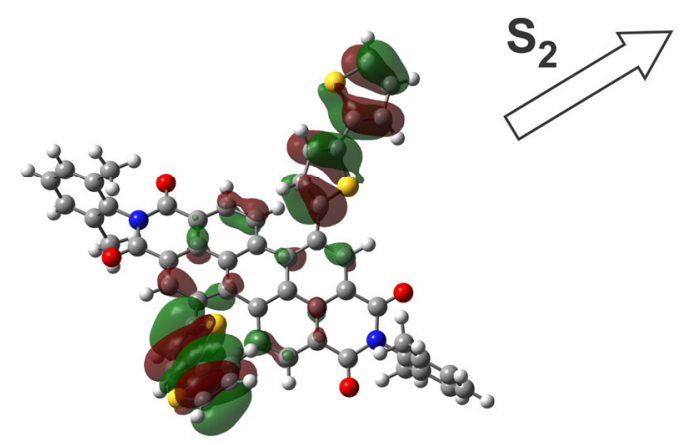

HOMO-1

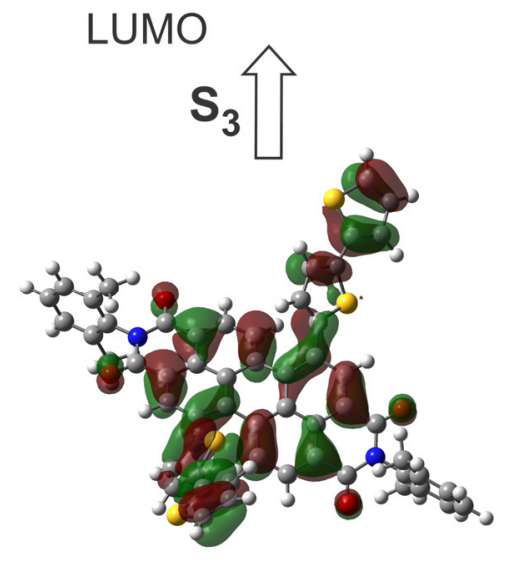

HOMO-2

Figure S7. Molecular orbitals corresponding to three lowest excited states for compound 2. Geometry optimization was performed at B3LYP/6-31G(d) level of theory with IEFPCM solvent treatment (chloroform); vertical excited state was calculated using corresponding time-dependent method. For computational efficiency, the molecule was truncated by replacing isopropyl groups with methyl groups.

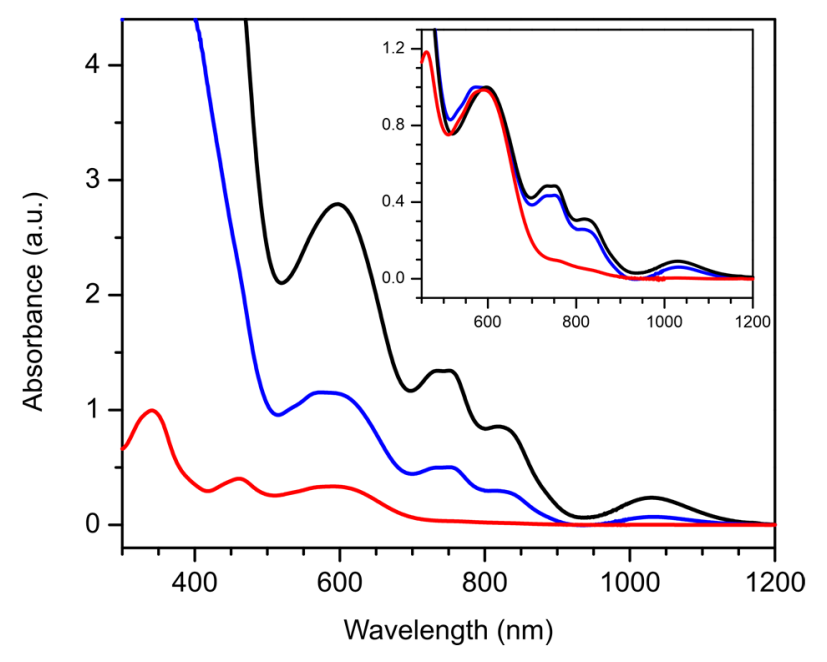

Figure S8. UV/vis absorption spectra of solutions of bis-Ni(II) catalytic initiator 4 in THF at $7{ }^{\circ} \mathrm{C}$. The trace color corresponds to concentration: black $0.15 \mathrm{mM}$, blue $0.1 \mathrm{mM}$, and red $0.03 \mathrm{mM}$. The insert shows the same spectra normalized at the peak intensity of the $610 \mathrm{~nm}$ band. 


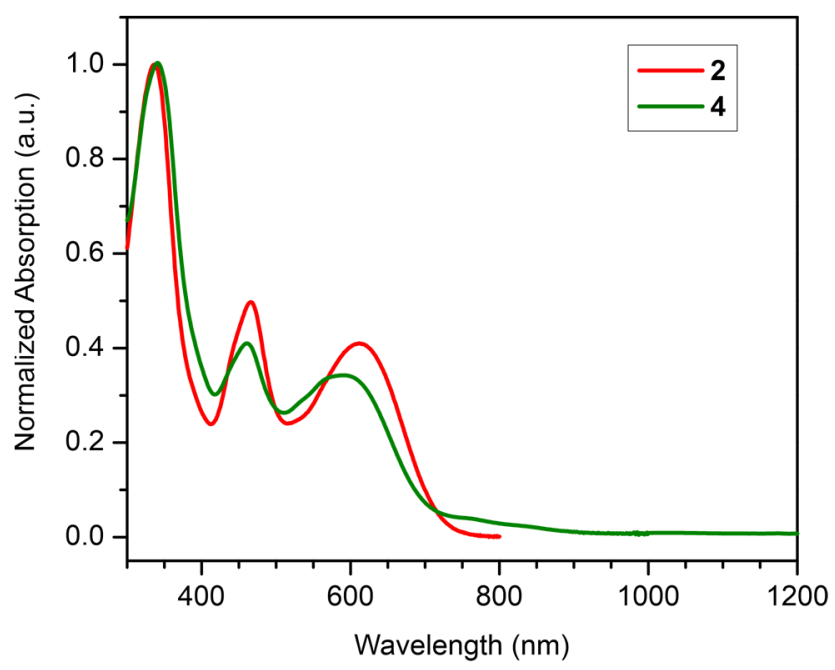

Figure S9. Normalized UV/vis absorption spectra of dilute solutions of PDCI compound 2 (in chloroform) and bis-Ni(II) catalytic initiator 4 (in THF).

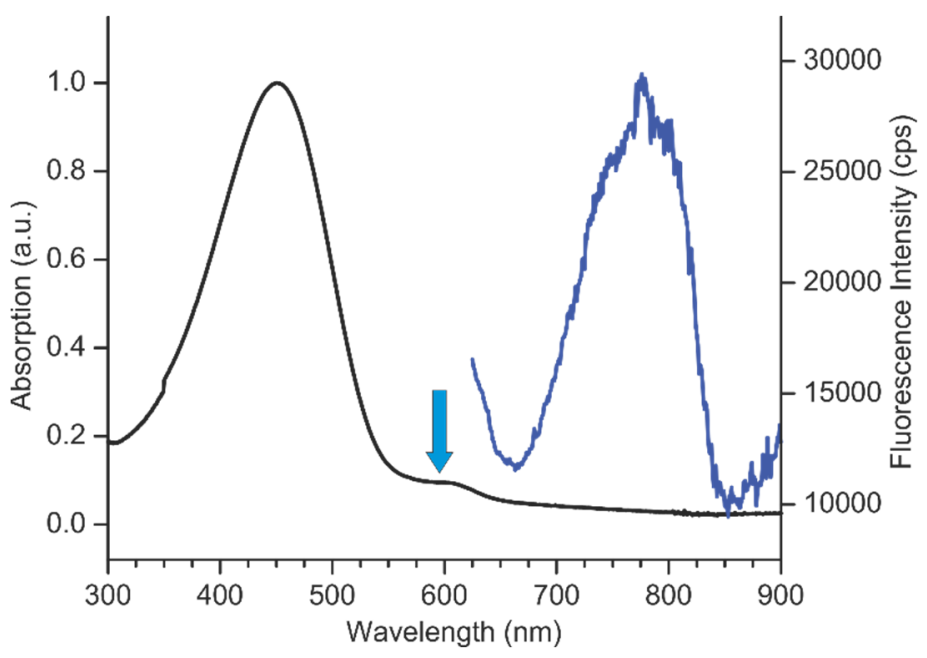

Figure S10. Absorption (black trace) and emission (blue trace) spectra of polymer $\mathbf{P 1}$ in $\mathrm{CHCl}_{3}$ solution. The emission spectrum was acquired upon direct excitation of the PDCI chromophore (the arrow shows position of the excitation).

\section{Experimental Section}

\section{General Procedures}

All reactions were performed under an atmosphere of dry nitrogen (unless mentioned otherwise).

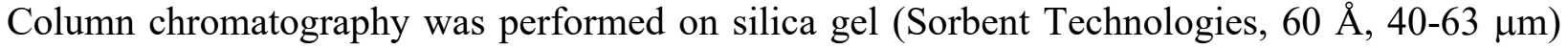
slurry packed into glass columns. Tetrahydrofuran (THF), ether, toluene, and hexane were dried by passing through activated alumina, and $N, N$-dimethylformamide (DMF) was dried by passing 
through molecular sieves, using a PS-400 Solvent Purification System from Innovative Technology, Inc. The water content of the solvents was periodically controlled by Karl Fischer titration (using a DL32 coulometric titrator from Mettler Toledo). Isopropylmagnesium chloride (2.0 M solution in THF) was purchased from Acros Organics, all other reagents and solvents were obtained from Aldrich and Alfa Aesar and used without further purification. Organometallic reagents were titrated with salicylaldehyde phenylhydrazone prior to use. ${ }^{1} \mathrm{UV} / \mathrm{vis}$ absorption spectra were recorded on Agilent Cary 5000 and Varian Cary 50 spectrometers. Variabletemperature UV/vis/NIR absorption spectra were acquired using a temperature-controlled Peltier cell holder installed in the Cary 5000 spectrometer. Fluorescence studies were carried out using a PTI QuantaMaster4/2006SE spectrofluorimeter equipped with a near-IR enhanced PMT detector and an integrating sphere for absolute quantum yield determinations. FT-IR spectra were acquired in $\mathrm{KBr}$ glasses using Bruker Vector 22 spectrometer. ${ }^{1} \mathrm{H}$ NMR spectra were recorded at 400 or $500 \mathrm{MHz}$, and are reported in ppm downfield from tetramethylsilane; ${ }^{31} \mathrm{P}$ NMR spectra were obtained at $162 \mathrm{MHz}$ and are reported in ppm relative to $80 \%$ aqueous $\mathrm{H}_{3} \mathrm{PO}_{4}$ as external standard. Ultrasonication was carried out using a Branson Sonifier 450 (400 W nominal power). GPC analysis of polymers was performed with an Agilent 1100 chromatograph equipped with two PLgel $5 \mu \mathrm{m}$ MIXED-C and one PLgel $5 \mu \mathrm{m} 1000 \AA ̊$ columns connected in series, using THF as a

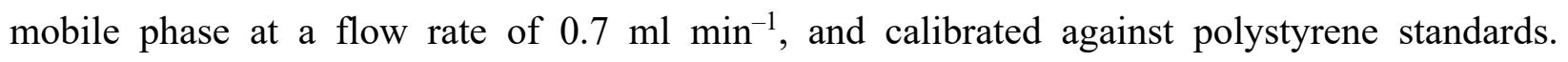
Differential scanning calorimetry (DSC) was performed using Shimadzu DSC-60 Plus system at a heating rate of $5{ }^{\circ} \mathrm{C} \mathrm{min}^{-1}$ in nitrogen atmosphere. SEM images were recorded on a Quanta 3D DualBeam FEG FIB scanning electron microscope with beam acceleration voltage of $20 \mathrm{kV}$. The SEM samples were prepared by dropcasting from a $\mathrm{CHCl}_{3}$ suspension onto a copper substrate. High resolution mass spectra were obtained at Bruker MaXis Plus LC/MS/MS Q-TOF system using ESI method. 


\section{Synthetic Details}

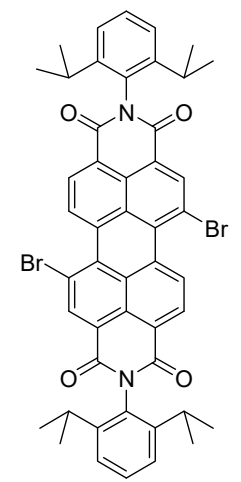

1

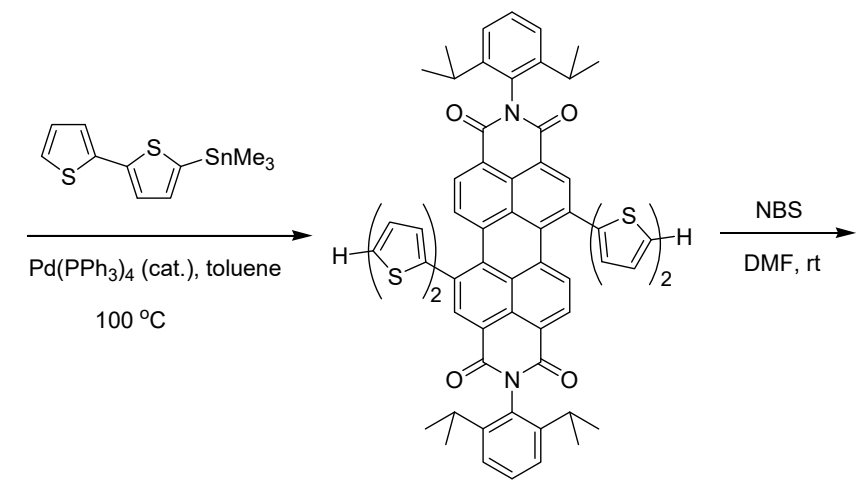

2

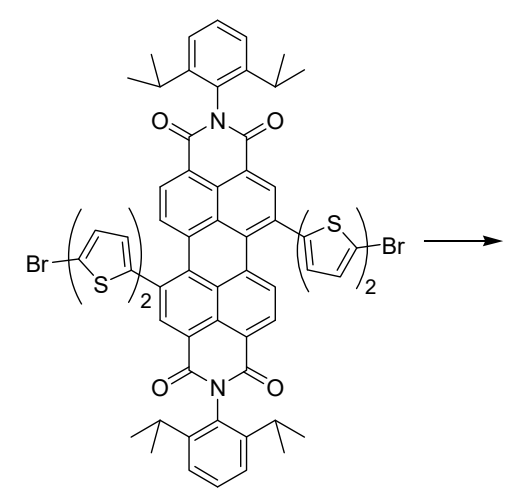

3

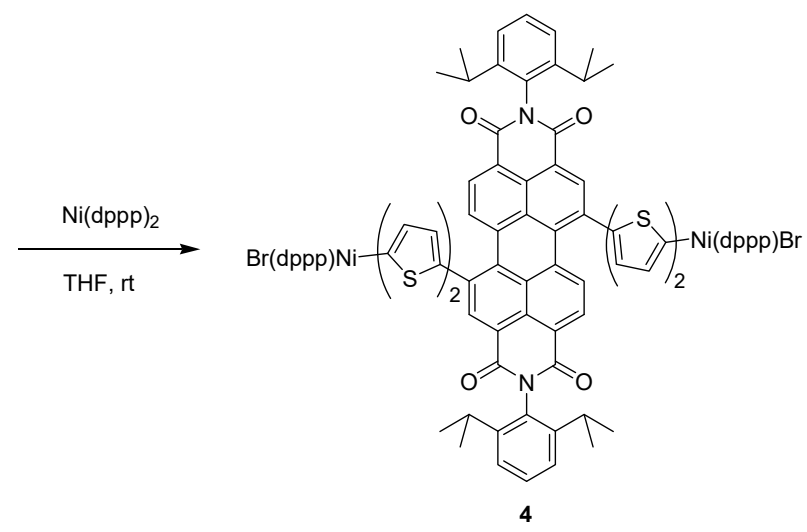

$N, N^{\prime}$-Di(2,6-diisopropylphenyl)-1,7-dibromoperylene-3,4:9,10-tetracarboxylic acid bisimide (1). Regioisomerically pure $\mathbf{1}$ was prepared following the literature procedure developed by Jager $e t$ al. ${ }^{2}$

\section{$N, N^{\prime}$-Di(2,6-diisopropylphenyl)-1,7-di(2,2'-bithien-5-yl)perylene-3,4:9,10-}

tetracarboxylic acid bisimide (2). A mixture of compound 1 (2.85 g, $3.28 \mathrm{mmol}), 5$ trimethylstannyl-2,2'-bithiophene ${ }^{3}$ (3.56 g, $\left.10.8 \mathrm{mmol}\right)$, and $\mathrm{Pd}\left(\mathrm{PPh}_{3}\right)_{4}(113 \mathrm{mg}, 0.098 \mathrm{mmol})$ in $320 \mathrm{ml}$ of toluene was heated upon stirring in a sealed Air-free flask at $100{ }^{\circ} \mathrm{C}$ for $12 \mathrm{~h}$. Upon reaction completion, the solvent was removed in vacuo and the crude product was purified by column chromatography on silica gel (eluent $\mathrm{CH}_{2} \mathrm{Cl}_{2}$ - hexanes 3:2) to yield $2.08 \mathrm{~g}(61 \%)$ of 2 as a black crystalline powder, $R_{\mathrm{f}} 0.29, \mathrm{mp} .>300{ }^{\circ} \mathrm{C} .{ }^{1} \mathrm{H} \mathrm{NMR}\left(500 \mathrm{MHz}, \mathrm{CD}_{2} \mathrm{Cl}_{2}\right) \delta 8.80(\mathrm{~s}, 2 \mathrm{H})$, $8.53(\mathrm{~d}, J=8.1 \mathrm{~Hz}, 2 \mathrm{H}), 8.39$ (d, $J=8.1 \mathrm{~Hz}, 2 \mathrm{H}), 7.55$ (t, $J=7.8 \mathrm{~Hz}, 2 \mathrm{H}), 7.42-7.37$ (m, 6H), $7.35(\mathrm{~d}, J=5.1 \mathrm{~Hz}, 2 \mathrm{H}), 7.33(\mathrm{~d}, J=3.5 \mathrm{~Hz}, 2 \mathrm{H}), 7.30(\mathrm{~d}, J=3.5 \mathrm{~Hz}, 2 \mathrm{H}), 7.10$ (t, $J=3.5 \mathrm{~Hz}$, 2H), 2.79 (septet, $J=6.8 \mathrm{~Hz}, 4 \mathrm{H}$ ), 1.18 (t, $J=6.8 \mathrm{~Hz}, 24 \mathrm{H}$ ). HRMS (ESI-TOF) $\mathrm{m} / z 1039.2732$ $\left[\mathrm{M}+\mathrm{H}^{+}\right]$(calcd. for $\mathrm{C}_{64} \mathrm{H}_{50} \mathrm{~N}_{2} \mathrm{O}_{4} \mathrm{~S}_{4}$ 1039.2743). 


\section{$N, N^{\prime}$-Di(2,6-diisopropylphenyl)-1,7-di(5'-bromo-2,2'-bithien-5-yl)perylene-3,4:9,10-}

tetracarboxylic acid bisimide (3). $N$-Bromosuccinimide $(0.70 \mathrm{~g}, 3.94 \mathrm{mmol})$ was added in small portions over $\sim 5 \mathrm{~min}$ to a stirred solution of $2.03 \mathrm{~g}(1.95 \mathrm{mmol})$ of 2 in $195 \mathrm{ml}$ of anhydrous DMF, and the resulting mixture was stirred at room temperature for $3 \mathrm{~h}$ in the absence of light. The reaction mixture was poured in water and extracted with ethyl acetate, and the organic layer was washed successively with a few portions of water and brine, dried over $\mathrm{Na}_{2} \mathrm{SO}_{4}$ and concentrated in vacuo. The crude solid was purified by column chromatography on silica gel upon elution with a $\mathrm{CH}_{2} \mathrm{Cl}_{2}$ - hexanes 3:2 mixture to yield $2.03 \mathrm{~g}(87 \%)$ of 3 as a black crystalline solid, $R_{\mathrm{f}} 0.25, \mathrm{mp}$. 293-295 ${ }^{\circ} \mathrm{C} .{ }^{1} \mathrm{H}$ NMR $\left(500 \mathrm{MHz}, \mathrm{CD}_{2} \mathrm{Cl}_{2}\right) \delta 8.79(\mathrm{~s}, 2 \mathrm{H}), 8.50(\mathrm{~d}, J=8.1 \mathrm{~Hz}, 2 \mathrm{H}), 8.40(\mathrm{~d}, J=$ $8.1 \mathrm{~Hz}, 2 \mathrm{H}), 7.55$ (t, $J=7.8 \mathrm{~Hz}, 2 \mathrm{H}), 7.42-7.38(\mathrm{~m}, 6 \mathrm{H}), 7.27$ (d, $J=3.8 \mathrm{~Hz}, 2 \mathrm{H}), 7.07$ (d, $J=$ $3.8 \mathrm{~Hz}, 2 \mathrm{H}), 7.04$ (d, $J=3.8 \mathrm{~Hz}, 2 \mathrm{H}), 2.78$ (septet, $J=6.8 \mathrm{~Hz}, 4 \mathrm{H}), 1.18$ (t, $J=6.8 \mathrm{~Hz}, 24 \mathrm{H}$ ). HRMS (ESI-TOF) $m / z 1195.0948\left[\mathrm{M}+\mathrm{H}^{+}\right]$(calcd. for $\mathrm{C}_{64} \mathrm{H}_{48} \mathrm{Br}_{2} \mathrm{~N}_{2} \mathrm{O}_{4} \mathrm{~S}_{4}$ 1195.0942).

Catalytic initiator (4). A mixture of compound 3 ( $50 \mathrm{mg}, 0.04 \mathrm{mmol})$ and $\mathrm{Ni}(\mathrm{dppp})_{2}(110$ $\mathrm{mg}, 0.12 \mathrm{mmol}$, prepared as described in ref. 4) in $10 \mathrm{ml}$ of dry THF was stirred at room temperature for $3 \mathrm{~h}$. The initiator solution (nominal concentration $4.18 \mathrm{mM}$ ) was used as prepared. ${ }^{31} \mathrm{P}$ NMR (162 MHz, THF) $\delta 18$ (br. $\left.\mathrm{m}, 1 \mathrm{P}\right),-5$ (br. $\mathrm{m}, 1 \mathrm{P}$ ). The broad signals in the ${ }^{31} \mathrm{P}$ NMR spectrum could be attributed to strong aggregation of the compound 4 .
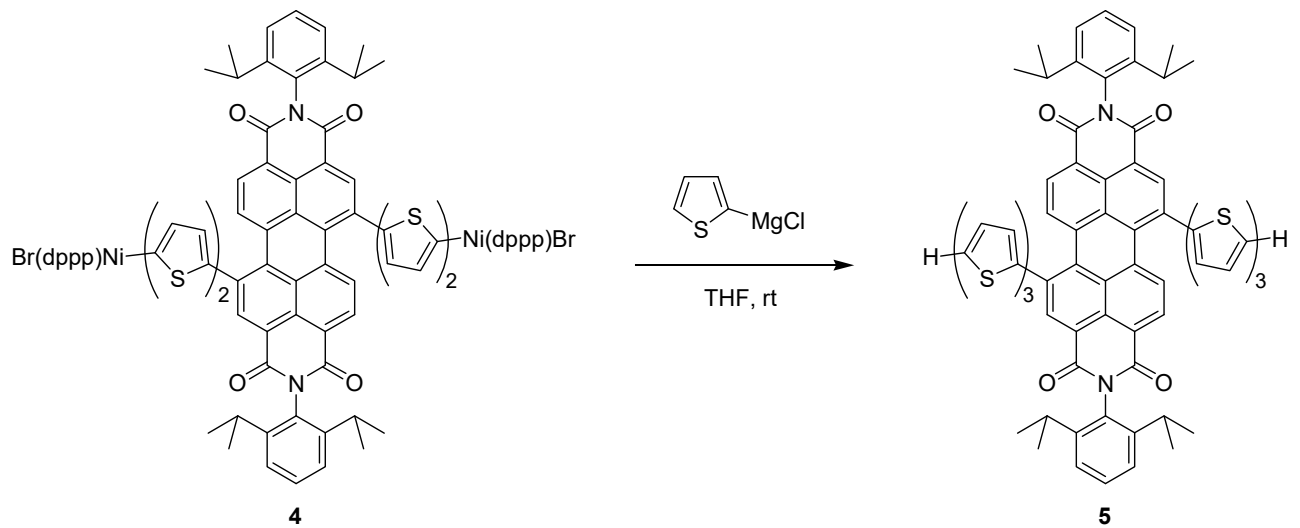

$N, N^{\prime}$-Di(2,6-diisopropylphenyl)-1,7-di(2,2':5',2"-terthiophen-5-yl)perylene-3,4:9,10tetracarboxylic acid bisimide (5). A mixture of $0.04 \mathrm{~g}(0.03 \mathrm{mmol})$ of 3 and $0.09 \mathrm{~g}(0.1 \mathrm{mmol})$ of $\mathrm{Ni}(\mathrm{dppp})_{2}$ in $5 \mathrm{ml}$ of anhydrous THF was stirred in an air-free flask at room temperature for 2 h. A solution of thiophen-2-ylmagnesium chloride ( $1 \mathrm{ml}$ of $0.1 \mathrm{M}$ solution in THF, $0.1 \mathrm{mmol}$ ) was added dropwise, and the reaction mixture was stirred for $1 \mathrm{~h}$ at room temperature. The reaction 
was quenched with $5 \mathrm{M} \mathrm{HCl}$ and poured into dichloromethane. The organic fraction was washed thoroughly with water, and dried over $\mathrm{Na}_{2} \mathrm{SO}_{4}$. Concentration in vacuo gave the crude product which was dissolved in minimal amount of $\mathrm{CH}_{2} \mathrm{Cl}_{2}$ and passed through a plug of silica gel eluted with dichloromethane. This yielded $23.2 \mathrm{mg}$ (58\%) of 5 as a black crystalline solid, mp. 168-172 ${ }^{\circ} \mathrm{C} .{ }^{1} \mathrm{H}$ NMR $\left(500 \mathrm{MHz}, \mathrm{CD}_{2} \mathrm{Cl}_{2}\right) \delta 8.81(\mathrm{~s}, 2 \mathrm{H}), 8.54(\mathrm{~d}, J=8.1 \mathrm{~Hz}, 2 \mathrm{H}), 8.41(\mathrm{~d}, J=8.1 \mathrm{~Hz}$, 2H), 7.55 (t, $J=7.8 \mathrm{~Hz}, 2 \mathrm{H}), 7.42$ (d, $J=3.8 \mathrm{~Hz}, 2 \mathrm{H}), 7.39(\mathrm{~d}, J=7.8 \mathrm{~Hz}, 4 \mathrm{H}), 7.34$ (d, $J=3.8$ $\mathrm{Hz}, 2 \mathrm{H}), 7.32$ (d, $J=5.1 \mathrm{~Hz}, 2 \mathrm{H}), 7.27$ (d, 3.7 Hz, 2H), 7.20 (d, J=3.8 Hz), 7.17 (d, J=3.8 Hz, 2H), $7.09\left(\mathrm{dd}, J_{1}=5.1, J_{2}=3.7 \mathrm{~Hz}\right), 2.79$ (septet, $\left.J=6.8 \mathrm{~Hz}, 4 \mathrm{H}\right), 1.18(\mathrm{t}, J=6.8 \mathrm{~Hz}, 24 \mathrm{H})$. HRMS (ESI-TOF) $m / z$ 1203.2481 [M+H $\left.{ }^{+}\right]$(calcd. for $\mathrm{C}_{72} \mathrm{H}_{54} \mathrm{~N}_{2} \mathrm{O}_{4} \mathrm{~S}_{6} 1203.2486$ ).
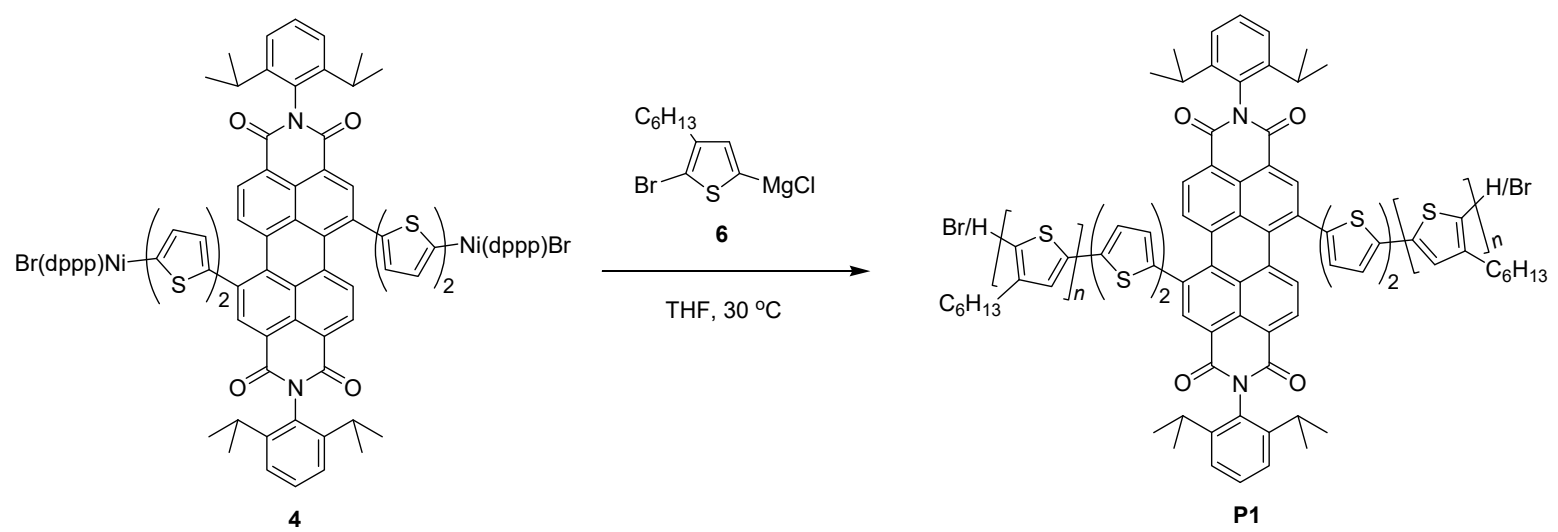

Polymer P1. A solution of $i-\mathrm{PrMgCl}(0.42 \mathrm{ml}$ of $2 \mathrm{M}$ solution in THF, $0.84 \mathrm{mmol})$ was added dropwise to a stirred solution of $0.25 \mathrm{~g}(0.76 \mathrm{mmol})$ of 2,5-dibromo-3-hexylthiophene in 12 $\mathrm{ml}$ of THF and stirred at $0{ }^{\circ} \mathrm{C}$ for $1 \mathrm{~h}$. An aliquot of catalytic initiator 4 (prepared as described above, $1.82 \mathrm{ml}$ of solution in THF, $7.6 \mu \mathrm{mol}, 1 \mathrm{~mol} \%$ ) was added to the Grignard reagent solution and the reaction mixture was stirred for $1 \mathrm{~h}$ at $30^{\circ} \mathrm{C}$. After the polymerization was complete, the reaction mixture was quenched with $250 \mu \mathrm{l}$ of $5 \mathrm{M} \mathrm{HCl}$ and precipitated into $150 \mathrm{ml}$ of methanol. The resulting precipitate was separated by centrifugation and washed with methanol to yield 0.11 $\mathrm{g}(86 \%)$ of $\mathbf{P 1}$ as a purple solid with metallic luster, $M_{\mathrm{n}} 12.5 \mathrm{kDa}$, PDI 1.06 (GPC, vs. polystyrene standards). ${ }^{1} \mathrm{H}$ NMR $\left(400 \mathrm{MHz}, \mathrm{CDCl}_{3}\right) \delta 8.82-8.68(\mathrm{~m}, 0.03 \mathrm{H}), 8.53-8.32(\mathrm{~m}, 0.06 \mathrm{H}), 7.60-$ $6.90(\mathrm{~m}, 0.24 \mathrm{H}), 6.98(\mathrm{~s}, 1 \mathrm{H}), 2.95-2.66(\mathrm{~m}, 2 \mathrm{H}), 1.79-1.53(\mathrm{~m}, 2 \mathrm{H}), 1.50-1.22(\mathrm{~m}, 6.36 \mathrm{H})$, $1.04-0.76(\mathrm{~m}, 3 \mathrm{H})$.

General Procedure for Preparing PDCI-PT Nanoparticles. A solution of $i$-PrMgCl ( $0.325 \mathrm{ml}$ of $1.80 \mathrm{M}$ solution in THF) was added dropwise to a solution of 2,5-dibromothiophene (150 mg, $0.62 \mathrm{mmol})$ in $12 \mathrm{ml}$ of dry THF at $0{ }^{\circ} \mathrm{C}$ and stirred for $1.5 \mathrm{~h}$ to afford a solution of the 
Grignard monomer 7. The prepared solution of 7 was brought to a required temperature using either ice/water mixture $\left(0\right.$ and $\left.7^{\circ} \mathrm{C}\right)$ or a digitally controlled aluminum heating block $\left(22^{\circ} \mathrm{C}\right)$, and was equilibrated at that temperature for $30 \mathrm{~min}$. An aliquot of the catalytic initiator solution 4 prepared as described above ( $1.5 \mathrm{ml}$ of $4.18 \mathrm{mM}$ solution, $6.3 \mu \mathrm{mol}, 1 \mathrm{~mol} \%)$ was quickly injected into the Grignard monomer solution. The reaction mixture was allowed to stir at $600 \mathrm{rpm}$ for 5 min, with temperature of the reaction mixture being maintained. Then, the reaction mixture was poured into $36 \mathrm{ml}$ of $25 \%(\mathrm{v} / \mathrm{v})$ solution of $\mathrm{CHCl}_{3}$ in methanol. The precipitate was collected by centrifugation (4000 rpm, $30 \mathrm{~min}$ ) and the solid was washed by re-suspending the solids in $30 \%$ (v/v) $\mathrm{MeOH}$ in $\mathrm{CHCl}_{3}$ upon ultrasonication, followed by another centrifugation step, and then additionally washed 3 times with $\mathrm{CHCl}_{3}$ in this manner until the supernatant was clear. The resulting maroon solid was dried under a gentle stream of $\mathrm{N}_{2}$.
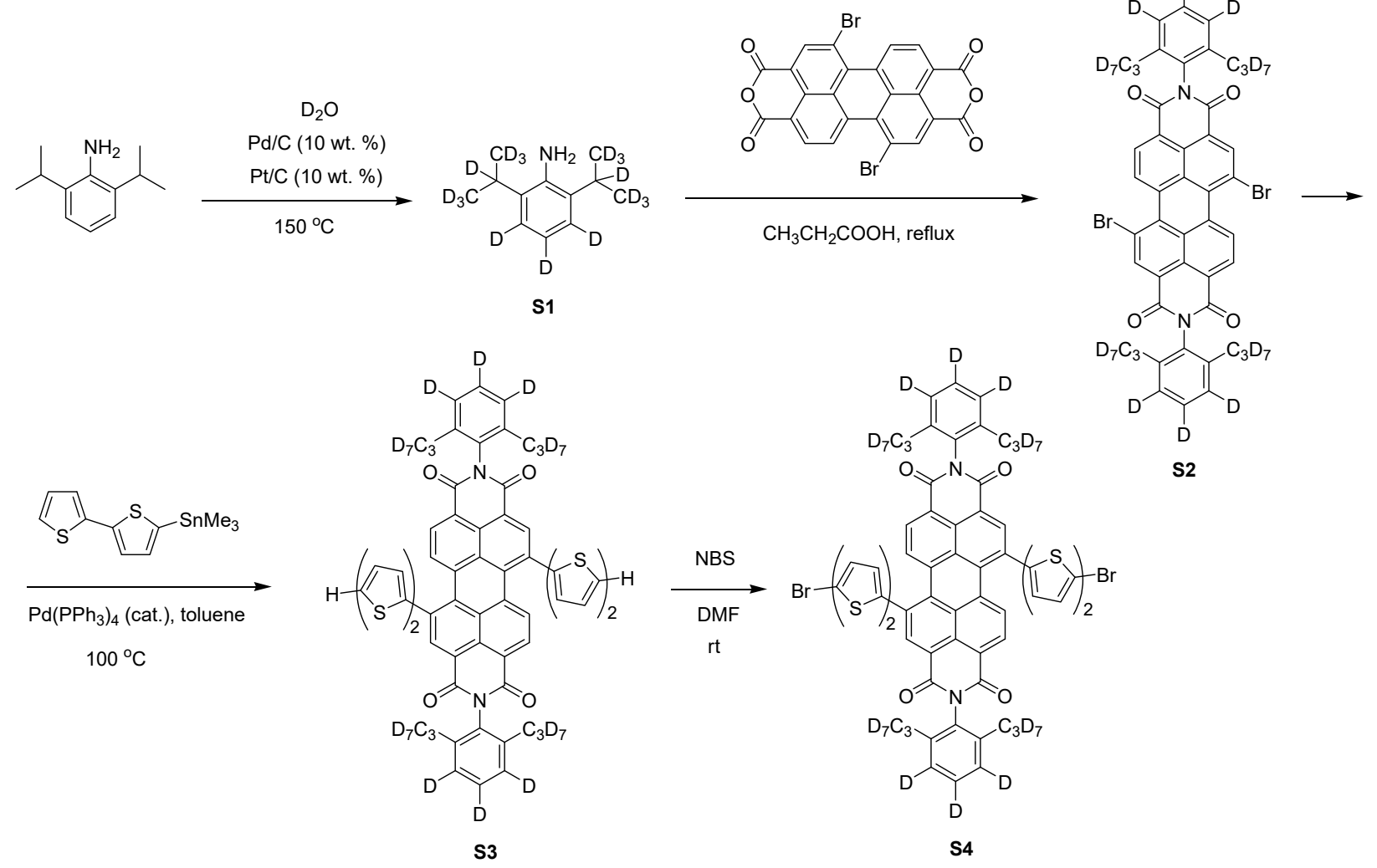

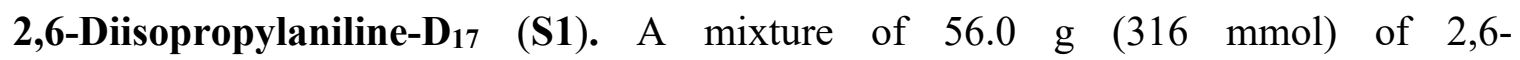
diisopropylaniline, $5.6 \mathrm{~g}$ of $10 \mathrm{wt}$ \% palladium on carbon, $5.6 \mathrm{~g}$ of $10 \mathrm{wt}$. \% of platinum on carbon, and $650 \mathrm{ml}(32.5 \mathrm{~mol})$ of $\mathrm{D}_{2} \mathrm{O}$ was loaded in a Parr reactor. The reactor was flushed with hydrogen 
gas for 15 minutes before it was sealed and heated to $150{ }^{\circ} \mathrm{C}$ upon stirring, with pressure reaching $180 \mathrm{psi}$, for $72 \mathrm{~h}$. After cooling to room temperature, the crude slurry was filtered, and the product was extracted from the filtrate using dichloromethane. The organic layer was dried over $\mathrm{MgSO}_{4}$ and concentrated in vacuo to yield $29.0 \mathrm{~g} \mathrm{(46 \% )}$ of S1 as a light brown oil which was used in the next step as obtained. HRMS (ESI-TOF) $m / z$ 195.2629 $\left[\mathrm{M}+\mathrm{H}^{+}\right]$(calcd. for $\mathrm{C}_{12} \mathrm{D}_{17} \mathrm{H}_{2} \mathrm{~N} 195.2663$ ).

$N, N^{\prime}$-Di(2,6-diisopropylphenyl-D 17 )-1,7-dibromoperylene-3,4:9,10-tetracarboxylic acid bisimide (S2). A mixture of 2,6-diisopropylaniline-D17 S1 (7.76 g, $39.52 \mathrm{mmol}$ ) and 1,7dibromoperylene-3,4:9,10-tetracarboxylic acid dianhydride ${ }^{2}(4.35 \mathrm{~g}, 7.9 \mathrm{mmol})$ in $150 \mathrm{ml}$ of propionic acid was stirred at reflux conditions for $72 \mathrm{~h}$. After cooling to room temperature, the reaction was poured into $1 \mathrm{~L}$ of ice-cold $\mathrm{H}_{2} \mathrm{O}$ and neutralized with saturated $\mathrm{NaHCO}_{3}$. The product was extracted with EtOAc, dried over $\mathrm{MgSO}_{4}$, and the solvent was removed in vacuo to yield a crude solid which was purified by column chromatography on silica gel (eluent $\mathrm{CH}_{2} \mathrm{Cl}_{2}$ - hexanes $4: 3)$ to yield $1.57 \mathrm{~g}$ of $\mathbf{S 2}$ as a red solid, $R_{\mathrm{f}}$ 0.15. The percent deuteration of 2,6-diisopropylphenyl group was at least $90 \%$ by ${ }^{1} \mathrm{H}$ NMR, with the 4-position having undergone the most significant hydrogen deuterium exchange in the acidic reaction conditions. HRMS (ESI-TOF) $\mathrm{m} / \mathrm{z} 900.3343$ $\left[\mathrm{M}^{+}\right]$(calcd. for $\mathrm{C}_{48} \mathrm{H}_{6} \mathrm{D}_{34} \mathrm{Br}_{2} \mathrm{~N}_{2} \mathrm{O}_{4} 900.3489$ ).

\section{$N, N^{\prime}$-Di(2,6-diisopropylphenyl-D 17$)-1,7-d i\left(2,2^{\prime}\right.$-bithien-5-yl)perylene-3,4:9,10-}

tetracarboxylic acid bisimide (S3). A mixture $1.57 \mathrm{~g}(1.74 \mathrm{mmol})$ of $\mathbf{S 2}, 1.70 \mathrm{~g}(5.16 \mathrm{mmol})$ of 5-trimethylstannyl-2,2'-bithiophene ${ }^{3}$ and $80 \mathrm{mg}(0.11 \mathrm{mmol})$ of $\mathrm{Pd}\left(\mathrm{PPh}_{3}\right)_{2} \mathrm{Cl}_{2}$ in $175 \mathrm{ml}$ of anhydrous toluene was stirred in a sealed Air-free flask at $100{ }^{\circ} \mathrm{C}$ for $18 \mathrm{~h}$. Subsequently, the solvent was removed in vacuo and the product was purified by column chromatography on silica gel (eluent $\mathrm{CH}_{2} \mathrm{Cl}_{2}$ - hexanes 3:2) to afford $0.73 \mathrm{~g}$ (39\%) of $\mathbf{S 3}$ as a black solid, $R_{\mathrm{f}}$ 0.3. HRMS (ESI-TOF) $m / z 1072.4720\left[\mathrm{M}^{+}\right]$(calcd. for $\mathrm{C}_{64} \mathrm{H}_{16} \mathrm{D}_{34} \mathrm{~N}_{2} \mathrm{O}_{4} \mathrm{~S}_{4} 1072.4788$ ).

\section{$N, N^{\prime}$-Di(2,6-diisopropylphenyl-D 17$)$-1,7-di(5'-bromo-2,2'-bithien-5-yl)perylene-}

3,4:9,10-tetracarboxylic acid bisimide (S4). $N$-Bromosuccinimide (243 $\mathrm{mg}, 1.37 \mathrm{mmol}$ ) was added in small portions over 10 minutes to a solution of $\mathbf{S 3}$ (733 $\mathrm{mg}, 0.68 \mathrm{mmol})$ in DMF, and the reaction mixture was stirred at room temperature for $3 \mathrm{~h}$. It was then poured in water and extracted with ethyl acetate. The organic layer was washed several times with $\mathrm{H}_{2} \mathrm{O}$, brine, and dried over $\mathrm{MgSO}_{4}$, and the solvent was removed in vacuo. The crude product was recrystallized from heptane 


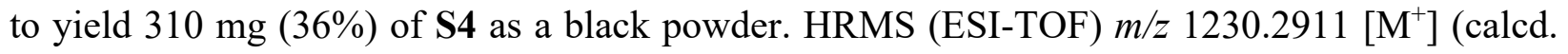
for $\mathrm{C}_{64} \mathrm{H}_{14} \mathrm{D}_{34} \mathrm{Br}_{2} \mathrm{~N}_{2} \mathrm{O}_{4} \mathrm{~S}_{4}$ 1230.2977).

Deuterated catalytic initiator $(d) 4$ was prepared following the procedure for catalytic initiator 4 starting with $130 \mathrm{mg}(0.11 \mathrm{mmol})$ of $\mathbf{S} 4$ and $286 \mathrm{mg}(0.32 \mathrm{mmol})$ of $\mathrm{Ni}(\mathrm{dppp})_{2}$ in 26 $\mathrm{ml}$ of THF. This resulted in a solution with nominal concentration of $4.18 \mathrm{mM}$ of (d)4.

2,5-Dibromothiophene- $\mathbf{D}_{\mathbf{2}}(\boldsymbol{d}) \mathbf{7}$. This compound was prepared according the procedure described in ref. 5 .

Preparation of $(d) \mathrm{PDCI}-\mathrm{PT}\left(0^{\circ} \mathrm{C}\right),(d) \mathrm{PDCI}-\mathrm{PT}\left(22^{\circ} \mathrm{C}\right), \mathrm{PDCI}-(d) \mathrm{PT}\left(0^{\circ} \mathrm{C}\right)$ and PDCI(d) PT $\left(22^{\circ} \mathrm{C}\right)$ was carried out following the general procedure described above for the preparation of corresponding non-deuterated nanoparticles and using deuterated $(d) 4$ or $(d) 7$ instead of the non-deuterated compounds.

Preparation of P1 nanoparticles by miniemulsion method was carried out as described in ref. 6. A sample of $15 \mathrm{mg}$ of polymer $\mathbf{P} 1$ was dissolved in $0.2 \mathrm{ml}$ of $\mathrm{CHCl}_{3}$ and added to $10 \mathrm{ml}$ of $0.055 \%$ aqueous solution of sodium dodecyl sulfate. The resulting biphasic solution was stirred for $1 \mathrm{~h}$ and then was ultrasonicated for $5 \mathrm{~min}$. The miniemulsion solution was then stirred at 62 ${ }^{\circ} \mathrm{C}$ for $3 \mathrm{~h}$ to remove $\mathrm{CHCl}_{3}$, and finally filtered through a $0.2 \mu \mathrm{m}$ syringe filter.

Determination of PDCI fraction by quantitative IR spectroscopy. Potassium bromide was oven dried at $110{ }^{\circ} \mathrm{C}$ overnight, and samples of compound $\mathbf{1}$ were dried overnight in vacuum. Quantitative mixtures of 1 and $\mathrm{KBr}$ (with concentration of $\mathbf{1}$ in the range of 0.01 to 0.48 wt. \%) were ground continuously for 10 minutes using an agate mortar and pestle. The $\mathrm{KBr}$ pellets for measurements were prepared by pressing a mixture of $\mathrm{KBr}$ powder and $\mathbf{1}$ at 16,000 $\mathrm{lbs}$ of pressure for 3 minutes until the pellet became transparent. The sample pellet's thickness was measured using a generic caliper with an accuracy of $0.02 \mathrm{~mm}$. An average of 3 thickness measurements were taken and used for calculations. The $\mathrm{PDCI}$ fragment features two strong $\mathrm{C}=\mathrm{O}$ stretching bands at 1671 and $1709 \mathrm{~cm}^{-1}$ (Figure S5). First, we determined an extinction coefficient for the $1709 \mathrm{~cm}^{-1}$ band using a series of finely dispersed samples of compound $\mathbf{1}$ at various concentrations (ranging from 0.01 to $0.48 \mathrm{wt} . \%$ ) in $\mathrm{KBr}$ glass. The average IR molar extinction coefficient was calculated for the band at $1709 \mathrm{~cm}^{-1}$, using the background absorbance at $1800 \mathrm{~cm}^{-1}$. Then, we 
finely ground PDCI-PT nanoparticles (using an agate mortar and pestle) and mixed the exact amounts of them with $\mathrm{KBr}$; the mixture was then pressed in $\mathrm{KBr}$ glass pellets for quantification of PDCI (Figure S6). The measured intensity of the band at $1709 \mathrm{~cm}^{-1}$ was used for calculations.

Powder X-ray diffraction (XRD) experiments. The high resolution synchrotron powder diffraction data were collected using beamline 11-BM at the Advanced Photon Source (APS), Argonne National Laboratory using an average wavelength of $\lambda=0.412764 \AA .^{7}$ Discrete detectors covering an angular range from -6 to $16^{\circ} 2 \theta$ were scanned over a $34^{\circ} 2 \theta$ range, with data points collected every $0.001^{\circ} 2 \theta$ and scan speed of $0.01 \%$ s. The nanoparticle samples were placed in Kapton capillaries, and the acquired data were background subtracted using background data file provided by 11-BM.

The coherence length $\xi$ was calculated from XRD data using the Scherrer equation:

$$
\xi=\frac{57.3 \lambda}{\sqrt{B^{2}-b_{0}^{2}} \cos \theta}
$$

where $B$ is the full-width at half-maximum of the (110) diffraction line (in $2 \theta$ ), $b_{0}$ is the instrumental resolution $\left(5.3 \times 10^{-4 \circ}\right.$ in $\left.2 \theta\right)$, and $\lambda$ is the wavelength of X-ray photons $(0.412764 \AA)$.

The crystallinity of the samples was determined using XRD data as a ratio of integrated intensity of the Bragg diffraction peaks to the total integrated intensity (Bragg peaks plus diffuse background). The integration was done using Origin 8.5.1 software.

Small-angle neutron scattering (SANS) experiments were carried out at the extended $Q$-range small-angle neutron scattering diffractometer (EQ-SANS) beamline (BL-6) at the Spallation Neutron Source (SNS) located at Oak Ridge National Laboratory (ORNL). Sample-to-detector distances of $1.3,4$ and $8 \mathrm{~m}$ were used with minimum wavelengths, $\lambda$, of 4,10 , and $12 \AA$, respectively at $60 \mathrm{~Hz}$ operation frequency, covering a $q$ range of $0.002 \AA^{-1}<q<0.6 \AA^{-1}$ where $q$ $=(4 \pi / \lambda) \sin (\theta / 2)$ is the magnitude of the scattering vector, and $\theta$ is the scattering angle. ${ }^{8,9}$ The measured scattering intensity was corrected according to standard procedures with Mantid Plot. ${ }^{10}$ Reduced scattering intensities were azimuthally averaged into $I(q)$ vs $q$ and placed on an absolute scale using a calibrated standard porous silica, which is known to have a scattering intensity 450 $\mathrm{cm}^{-1}$ at very small $q$. Samples with concentration of $5 \mathrm{mg} \mathrm{ml}^{-1}$ in deuterated 1,2-dichlorobenzene 
were suspended by ultrasonication before experiments. Titanium sample cells with quartz windows and a $1 \mathrm{~mm}$ path length were used.

Computational studies. DFT computations were carried out using Gaussian 16 computational package running on a Windows-based computer. ${ }^{11}$ Geometry optimization of a truncated compound 2 (four isopropyl substituents replaced with methyl groups) was carried out at a B3LYP/6-31G* level with IEFPCM solvation treatment (solvent chloroform), and frequency analysis was performed on the optimized structure to check for a true minimum. Subsequent timedependent DFT single-point computations at the same level of theory were done on the optimized structure to identify 6 lowest-energy singlet vertical (Franck-Condon) excited states. The obtained geometry, molecular orbitals, and electron density difference surfaces were visualized using Gauss View program. ${ }^{12}$ 


\section{Additional NMR Spectra}

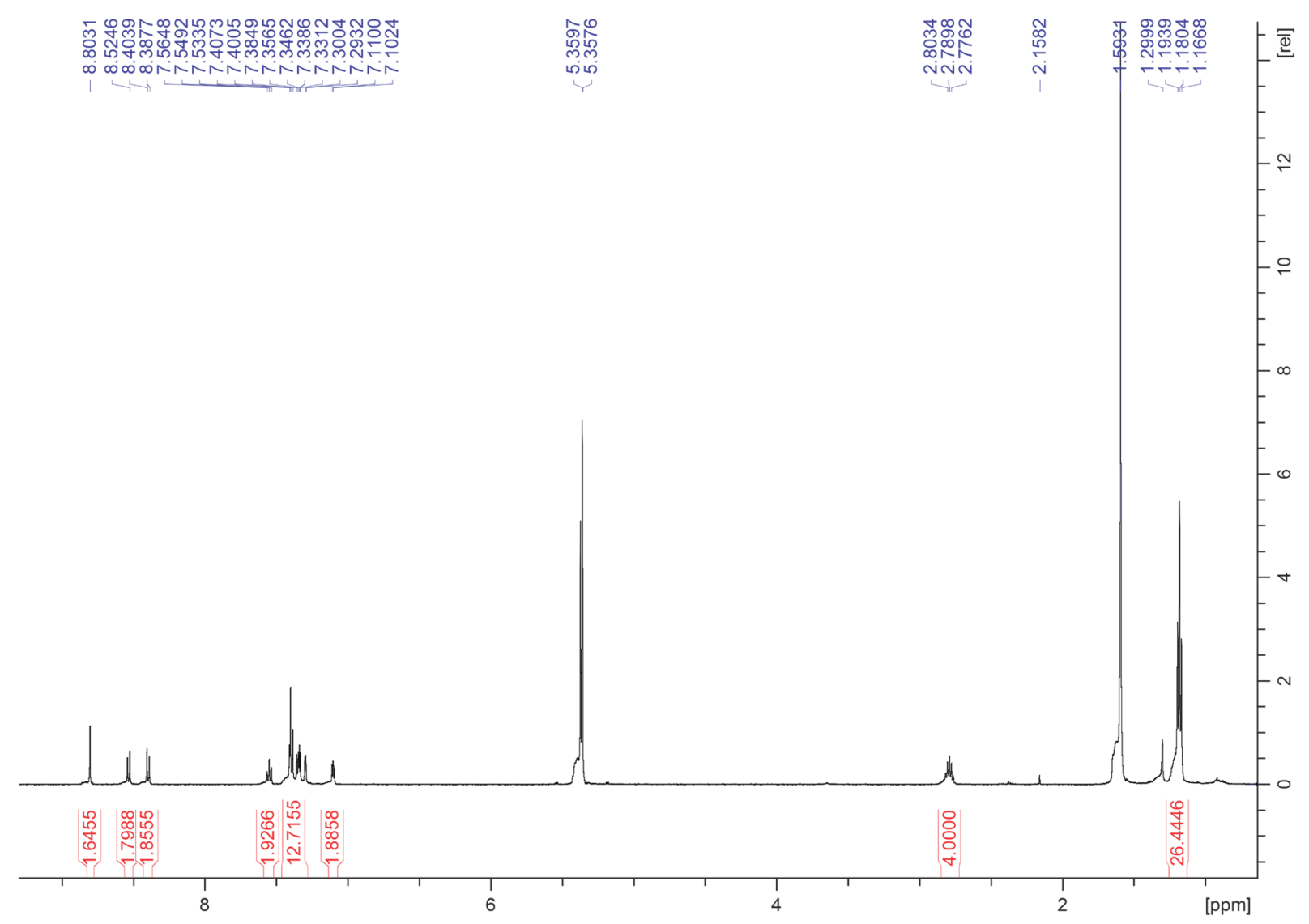

Figure S11. ${ }^{1} \mathrm{H}$ NMR spectrum $\left(500 \mathrm{MHz}, \mathrm{CD}_{2} \mathrm{Cl}_{2}\right)$ of compound 2. 


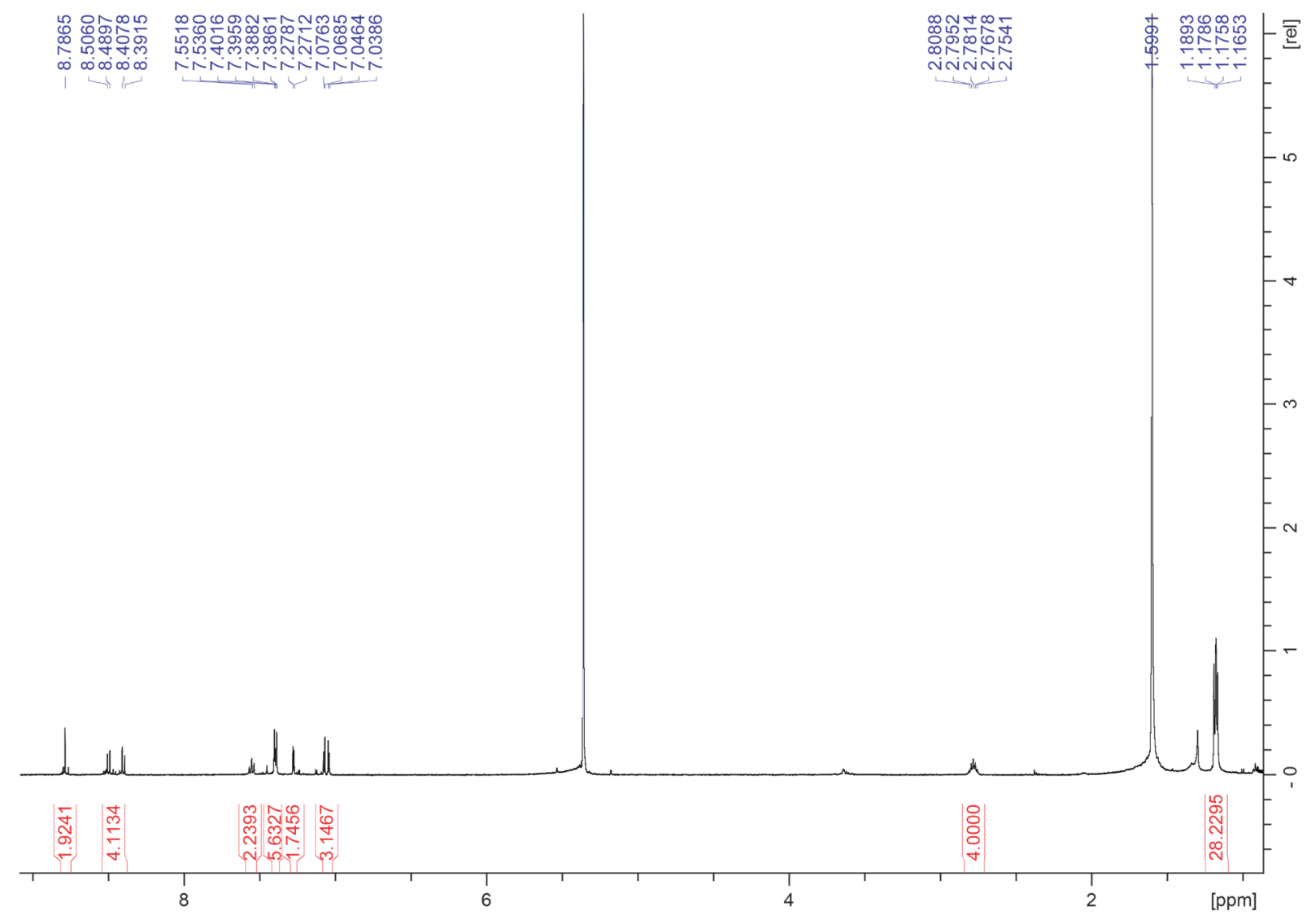

Figure S12. ${ }^{1} \mathrm{H}$ NMR spectrum $\left(500 \mathrm{MHz}, \mathrm{CD}_{2} \mathrm{Cl}_{2}\right)$ of compound 3. 


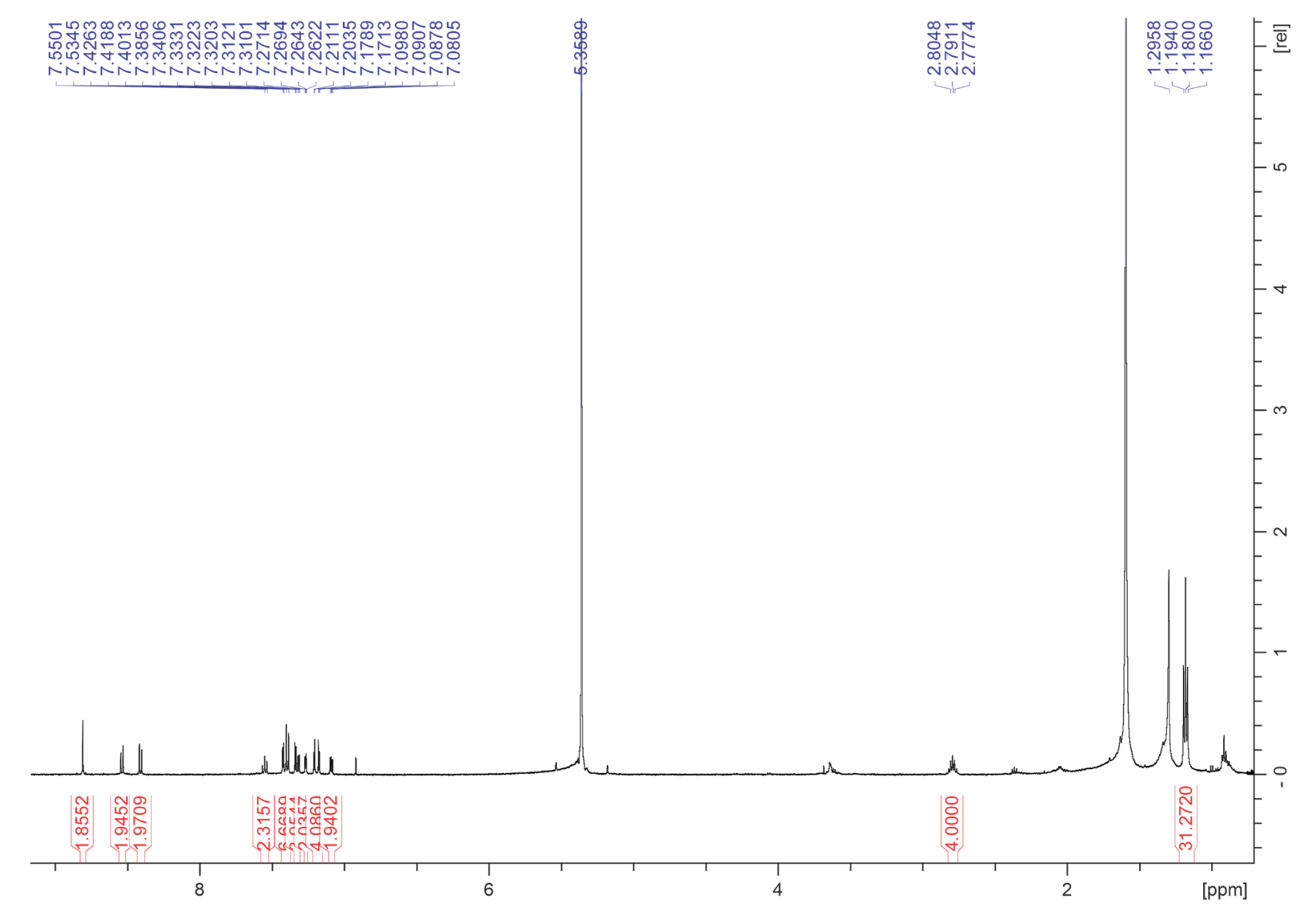

Figure S13. ${ }^{1} \mathrm{H}$ NMR spectrum $\left(500 \mathrm{MHz}, \mathrm{CD}_{2} \mathrm{Cl}_{2}\right)$ of compound 5.

\section{$\underline{\text { References }}$}

(1) Love, B. E.; Jones, E. G. The use of salicylaldehyde phenylhydrazone as an indicator for the titration of organometallic reagents. J. Org. Chem. 1999, 64, 3755-3756.

(2) Sengupta, S.; Dubey, R. K.; Hoek, R.-W. M.; van Eeden, S.-P. P.; Gunbas, D. D.; Grozema, F. C.; Sudholter, E.-J. R.; Jager, W. F. Synthesis of regioisomerically pure 1,7-dibromoperylene3,4,9,10-tetracarboxylic acid derivatives. J. Org. Chem. 2014, 79, 6655-6662.

(3) Bilge, A.; Zen, A.; Forster, M.; Li, H.; Galbrecht, F.; Nehls, B. S.; Farrell, T.; Neher, D.; Scherf, U. Swivel-crusiform oligothiophene dimers. J. Mater. Chem. 2006, 16, 3177-3182.

(4) Chavez, C. A.; Choi, J.; Nesterov, E. E. One-step simple preparation of catalytic initiators for catalyst-transfer Kumada polymerization: synthesis of defect-free polythiophenes. Macromolecules 2014, 47, 506-516.

(5) Youm, S. G.; Hwang, E.; Chavez, C. A.; Li, X.; Chatterjee, S.; Lusker, K. L.; Lu, L.; Strzalka, J.; Ankner, J. F.; Losovyj, Y.; Garno, J. C.; Nesterov, E. E. Polythiophene thin films by surface-initiated polymerization: mechanistic and structural studies. Chem. Mater. 2016, 28, 4787-4804. 
(6) Landfester, K.; Montenegro, R.; Scherf, U.; Güntner, R.; Asawapirom, U.; Patil, S.; Neher, D.; Kietzke, T. Semiconducting polymer nanospheres in aqueous dispersion prepared by a miniemulsion process. Adv. Mater. 2002, 14, 651-655.

(7) Wang, J.; Toby, B. H.; Lee, P. L.; Ribaud, L.; Antao, S.; Kurtz, C.; Ramanathan, M.; Von Dreele, R. B.; Beno, M. A. A dedicated powder diffraction beamline at the Advanced Photon Source: Commissioning and early operation results. Rev. Sci. Instrum. 2008, 79, 085105.

(8) Zhao, J. K.; Gao, C. Y.; Liu, D. The extended $Q$-range small-angle neutron scattering diffractometer at the SNS. J. Appl. Cryst. 2010, 43, 1068-1077.

(9) Wignall, G. D.; Bates, F. S. Absolute calibration of small-angle neutron scattering data. J. Appl. Cryst. 1987, 20, 28-40.

(10) Arnold, O.; Bilheux, J. C.; Borreguero, J. M.; Buts, A.: Campbell, S. I.; Chapon, L.; Doucet, M.; Draper, N.; Leal, R. F.; Gigg, M. A.; Lynch, V. E.; Markvardsen, A.; Mikkelson, D. J.; Mikkelson, R. L.; Miller, R.; Palmen, K.; Parker, P.; Passos, G.; Perring, T. G.; Peterson, P. F. et al. Mantid - Data analysis and visualization package for neutron scattering and $\mu \mathrm{SR}$ experiments. Nucl. Instrum. Methods Phys. Res., Sect. A 2014, 764, 156-166.

(11) Gaussian 16, Revision C.01, Frisch, M. J.; Trucks, G. W.; Schlegel, H. B.; Scuseria, G. E.; Robb, M. A.; Cheeseman, J. R.; Scalmani, G.; Barone, V.; Petersson, G. A.; Nakatsuji, H.; Li, X.; Caricato, M.; Marenich, A. V.; Bloino, J.; Janesko, B. G.; Gomperts, R.; Mennucci, B.; Hratchian, H. P.; Ortiz, J. V.; Izmaylov, A. F.; Sonnenberg, J. L.; Williams-Young, D.; Ding, F.; Lipparini, F.; Egidi, F.; Goings, J.; Peng, B.; Petrone, A.; Henderson, T.; Ranasinghe, D.; Zakrzewski, V. G.; Gao, J.; Rega, N.; Zheng, G.; Liang, W.; Hada, M.; Ehara, M.; Toyota, K.; Fukuda, R.; Hasegawa, J.; Ishida, M.; Nakajima, T.; Honda, Y.; Kitao, O.; Nakai, H.; Vreven, T.; Throssell, K.; Montgomery, J. A., Jr.; Peralta, J. E.; Ogliaro, F.; Bearpark, M. J.; Heyd, J. J.; Brothers, E. N.; Kudin, K. N.; Staroverov, V. N.; Keith, T. A.; Kobayashi, R.; Normand, J.; Raghavachari, K.; Rendell, A. P.; Burant, J. C.; Iyengar, S. S.; Tomasi, J.; Cossi, M.; Millam, J. M.; Klene, M.; Adamo, C.; Cammi, R.; Ochterski, J. W.; Martin, R. L.; Morokuma, K.; Farkas, O.; Foresman, J. B.; Fox, D. J. Gaussian, Inc., Wallingford CT, 2016.

(12) GaussView, Version 6.1.1, Dennington, R.; Keith, T. A.; Millam, J. M. Semichem Inc., Shawnee Mission, KS, 2016. 